\title{
UPPER TRIASSIC CORAL COMMUNITIES FROM THE OMAN MOUNTAINS: OCCURRENCE AND DISTRIBUTION PATTERN
}

BERNECKER, Michaela, Institute of Paleontology, Loewenichstr. 28, D-91054 Erlangen, Germany

Upper Triassic scleractinians from the Hawasina Complex (Oman Mountains) were investigated for the first time with respect to taxonomy and community structure. The 'Oman Exotics' are tectonically dislocated blocks, which formed isolated carbonate platforms on seamounts in the Hawasina basin. The investigated reefal limestone is dated as Norian/Rhaetian by benthic foraminiferal associations (Costifera, Siculocosta, Kaeveria, Galeanella). This age is supported by characteristic encrusting organisms (Alpinophragmium, Microtubus). Some small "Oman Exotics" are of Carnian age.

The fauna and flora include scleractinian corals of different growth form, 'sphinctozoans', 'inozoans', chaetetids, spongiomorphids, disjectoporids and solenoporacean algae as main reef builders, various encrusters like microbes, foraminifers, sponges and many different problematical organisms for the stabilisation of the reef framework and a group of dwellers including benthic foraminifers, gastropods and bivalves.

The coral communities are characterized by the coverage of organisms and distributional pattern. Field data were derived from studies of $29000 \mathrm{~cm}^{2}$ mapped reef fabric. Three coral communities were differentiated: (A) Diverse coral community: This community is most frequent and dominated by corals of different morphotypes; a subdivision into subcommunities is not useful because of gradual boundaries. Measurement parameters: (1) total detrital framework coverage: $15 \%$ (2) coverage of reefbuilders: corals $88 \%$, crinoids $5 \%$, "Spongiostromata" crusts $3 \%$, chaetetids $3 \%$, solenoporaceans $1 \%$. (B) Coral "Spongiostromata" community: Striking organisms are scleractinians and extended "Spongiostromata" crusts already visible in the outcrop. Measurement parameters: (1) total detrital framework coverage: $29 \%$ (2) coverage of reefbuilders: corals $58 \%$, "Spongiostromata" crusts $33 \%$, chaetetids $3 \%$, solenoporaceans $3 \%$, crinoids $3 \%$, chaetetids $3 \%$ (3) diameter of organisms of a group: dendroid corals $5-12.4 \mathrm{~cm}$, cerioid corals $31-20.4 \mathrm{~cm}$, "Spongiostromata" crusts $4.2 \mathrm{~cm}$. (C) Solenoporacean dendroid coral community: The solenoporaceans have a domal to bushy growth form, scleractinians are represented by slender dendroid colonies. Measurement parameters: (1) total detrital framework coverage: $26 \%$ (2) coverage of reefbuilders: solenoporaceans $75 \%$, dendroid corals $21 \%$, chaetetids $4 \%$ (3) diameter of organisms of a group: solenoporaceans 0.3 $-5.1 \mathrm{~cm}$, dendroid corals $6-22.4 \mathrm{~cm}$.

The morphotypes of the Upper Triassic scleractinians comprise the solitary corals Procyclolites triadicus FRECH 1890, Distichophyllia norica (FRECH 1890), Margarophyllia crenata (MÜNSTER 1841), the dendroid/phaceloid colonies of Cyclophyllia cyclica (SCHÄFER \& SENOWBARI-DARYAN 1978), Retiophyllia norica (FRECH 1890), Volzeia badiotica (VOLZ 1896), Margarosmilia zieteni KLIPSTEIN 1843), Margarosmilia charlyana (FRECH 1890), Rhopalodendron juliensis TURNSEK 1989 and the cerioid/thamnasteroid colonies of Pamiroseris rectilamellosa (WINKLER 1861), Gablonzeria profunda REUSS 1854, Astraeomorpha crassisepta REUSS 1854, Seriastraea multiphylla SCHÄFER \& SENOWBARI-DARYAN 1978. 3 Carnian taxa and 10 Norian taxa were determined.

Analogies with the coeval reef deposits from the European part of the Tethys have been recognized. Some species, collected now in Oman, were also reported from American and Asian localities. 